\title{
CURRENT ISSUES IN PUBLIC SECTOR ECONOMICS
}




\section{CURRENT ISSUES IN ECONOMICS}

General Editor: David Greenaway, University of Nottingham

Current Issues in Microeconomics

Edited by John D. Hey

Current Issues in Macroeconomics

Edited by David Greenaway

Current Issues in Labour Economics

Edited by David Sapsford and Zafiris Tzannatos

Current Issues in International Monetary Economics

Edited by David T. Llewellyn and Chris Milner

Current Issues in Development Economics

Edited by V. N. Balasubramanyam and Sanjaya Lall

Current Issues in Financial and Monetary Economics

Edited by Kevin Dowd and Mervyn K. Lewis

Current Issues in Public Sector Economics

Edited by Peter M. Jackson

Forthcoming

Current Issues in Industrial Economics

Edited by John Cable

Current Issues in Welfare Economics

Edited by Nicholas Barr and David Whynes

Current Issues in Agricultural Economics

Edited by A. J. Rayner and David R. Colman 


\title{
Current Issues in Public Sector Economics
}

\author{
Edited by
}

Peter M. Jackson

Macmillan Education 
ISBN 978-0-333-53484-7 ISBN 978-1-349-22409-8 (eBook)

DOI 10.1007/978-1-349-22409-8

Selection and editorial matter (C) Peter M. Jackson 1992

Individual chapters $@$ C Richard R. Barnett, Richard M. Bird, Vani K. Borooah, Peter M. Jackson, David M. King, Peter J. Lambert, Rosella Levaggi, David J. Pyle, Ian Walker 1992

Softcover reprint of the hardcover 1st edition 1992

All rights reserved. For information, write:

Scholarly and Reference Division,

St. Martin's Press, Inc., 175 Fifth Avenue, New York, N.Y. 10010

First published in the United States of America in 1992

ISBN 978-0-312-07995-6

Library of Congress Cataloging-in-Publication Data

Current issues in public sector economics / edited by Peter M.

Jackson.

p. cm.- (Current issues in economics: vol. 7)

Includes bibliographical references and index.

ISBN 978-0-312-07995-6

1. Finance, Public. 2. Social choice. I. Jackson, P. M. (Peter McLeod) II. Series.

HJ117.C87 1992

$92-6930$

$336-\mathrm{dc} 20$

CIP 
To my mother and father Betty and Andrew 


\section{Contents}

LIST OF TABLES IX ix

LIST OF FIGURES $\quad$ X

SERIES EDITOR'S PREFACE Xii

NOTES ON THE CONTRIBUTORS Xiv

1 INTRODUCTION: THE CURRENT STATE OF PUBLIC SECTOR ECONOMICS

Peter M. Jackson 1

2 TAXATION, PUBLIC CHOICE AND PUBLIC SPENDING

Peter M. Jackson 6

3 INCOME TAXATION, INCOME SUPPORT

POLICIES AND WORK INCENTIVES IN THE UK

Ian Walker

4 THE ECONOMICS OF TAXPAYER COMPLIANCE

D. J. Pyle

5 PREFERENCE REVELATION AND PUBLIC GOODS

Richard R. Barnett 
viii

6 PUBLIC CHOICE: AN INTRODUCTORY SURVEY

Vani K. Borooah

7 ISSUES IN MULTI-LEVEL GOVERNMENT David King

8 PUBLIC FINANCE IN DEVELOPING COUNTRIES

Richard M. Bird

9 THE DISTRIBUTION AND REDISTRIBUTION OF INCOME

Peter J. Lambert

10 ASYMMETRY OF INFORMATION IN PUBLIC FINANCE

Rosella Levaggi

END NOTES

254

BIBLIOGRAPHY

266

AUTHOR INDEX

290

SUBJECT INDEX

296 


\section{List of Tables}

3.1 Marginal rates and the 1988 social security reforms 47

3.2 Male labour supply estimates $\quad 51$

3.3 Female labour supply elasticities 51

3.4 Simulation results for transferable allowances $\quad 55$

4.1 Compliance costs of the UK personal tax system, 1973

5.1 Clarke-Groves tax 107

5.2 Clarke-Groves taxes and incentives 109

6.1 First-past-the-post voting 139

6.2 Multi-stage voting $\quad 140$

6.3 Paradox of voting 140

10.1 Asymmetry of information or master-servant problems $\quad 229$

10.2 Two-party game 242 


\section{List of Figures}

2.1 Optimal taxes 17

3.1 Labour supply, welfare and taxation $\quad 35$

3.21984 earnings and the NI LEL 41

3.3 1986 earnings and the NI LEL and thresholds 42

3.4 Hours distribution for UB wives 44

3.5 Hours of married mothers 46

3.6 Hours of lone mothers $\quad 46$

3.7 Pre and post social security reform poverty trap $\quad 47$

3.8 Employer NI contributions 49

3.9 Transferable allowances reform 53

4.1 Optimal tax evasion $\quad 65$

4.2 A change in the income tax rate 66

4.3 A change in the penal rate of tax 67

4.4 An increase in the income tax rate: Yitzhaki case . 68

4.5 The trade-off between certainty and severity of punishment 85

4.6 Differential audit probabilities by income tax group $\quad 86$

4.7 The optimal level of tax evasion $\quad 88$

5.1 Closed-ended matching grants $\quad 120$

5.2 Lump-sum and matching grants 121

5.3 Flypaper effect $\quad 125$

6.1 The median voter decides 141

6.2 Median voter outcomes under two-party
competition

6.3 The social costs of monopoly with rent seeking 144

6.4 The optimal political business cycle 152

9.1 Typical Lorenz curve 203

9.2 Two hypothetical Lorenz curve configurations 204 
9.3 Social decision-maker's imposed utility of income function

9.4 Generalised Lorenz curves

9.5 Single intersection of generalised Lorenz curves

9.6 Degrees of concavity

9.7 The inequality-reducing effect of a progressive income tax

9.8 Single and double crossing income tax reforms

10.1 Perfect information

10.2 Hidden information case 235

10.3 Income consumption curve problem 240

10.4 No cheating case

10.5 Cheating case: periods one to three 244

10.6 Cheating case: period four 245

10.7 Two-price system: cheating in period four 248 


\section{Series Editor's Preface}

The Current Issues series has slightly unusual origins. Current Issues in International Trade, which was published in 1987, and which turned out to be the pilot for the series was in fact 'conceived' in the Horton Hospital, Banbury, and 'delivered' (in the sense of completed) in the Hilton International in Nicosia! The reader may be struck by the thought that a more worthwhile and enjoyable production process would start and finish the other way around. I agree! Be that as it may, that is how the series started.

As I said in the Preface to Current Issues in International Trade the reason for its creation was the difficulty of finding suitable references on 'frontier' subjects for undergraduate students. Many of the issues which excite professional economists and which dominate the journal literature take quite a time to percolate down into texts; hence the need for a volume of Current Issues. The reception which Current Issues in International Trade received persuaded me that it would be worth doing something similar for the other subject areas we teach. Thus each volume in this series is intended to take readers to the 'frontier' of the particular subject area. Each volume contains nine or ten essays, one of which provides a general overview while the remainder are devoted to current issues.

As series editor the main challenge I faced was finding suitable editors for each of the volumes - the best people are generally the busiest! I believe, however, that I have been fortunate in having such an impressive and experienced team of editors with the necessary skills and reputation to persuade first-class authors to participate. I would like to thank all of them for their cooperation 
and assistance in the development of the series. Like me, all of them will, I am sure, hope that this series provides a useful service to undergraduate and graduate students as well as faculty.

Current Issues in Public Sector Economics is the seventh in the series. This has been an area of some considerable interest over the last decade, with changes in the financing and delivery of public services and changes in the structure of taxation in the UK and elsewhere. These and other issues have helped keep the public sector at the top of the policy agenda. Many of these topical issues are covered in this volume, some covered in Current Issues in Welfare Economics. The present volume focuses much more on taxation issues, whilst the emphasis in Current Issues in Welfare Economics will be more towards expenditure issues.

The editor of this volume has selected topics where theoretical innovation has been important, as in the case of public choice and preference revelation, as well as topics with a strong policy focus, like income distribution and redistribution and public finance in developing countries. The combination of theory, policy and empirics makes for a well-balanced set of readings, with papers that have been carefully written and carefully edited.

The appropriate role of the public sector in mixed economies is a topic of ongoing interest and will ensure that public sector economics continues to figure as a major final-year undergraduate course. I hope that these essays will be useful and interesting to students of that subject. 


\section{Notes on the Contributors}

Richard R. Barnett is Professor of Public Finance and Management at the University of Ulster. He has previously taught at the Universities of Salford and York and at Queen's University, Ontario, and has held the Vivienne Stewart Visiting Fellowship at the University of Cambridge. His research interests lie in the general areas of intergovernmental fiscal relations and the economics and management of public policy.

Richard M. Bird is Professor of Economics at the University of Toronto. His main interest is in public finance and development. His numerous publications in that field include two recent books, Taxation in Developing Countries, edited with Oliver Oldman, and Tax Policy and Economic Development.

Vani K. Borooah is Professor of Applied Economics at the University of Ulster. He was previously a Senior Research Officer in the Department of Applied Economics at Cambridge University and a Fellow of Queens' College, Cambridge. He has published widely on the topic of political economy and public choice and is a member of the management committee of the European Public Choice Society. His publications include Political Aspects of the Economy.

Peter M. Jackson is Professor of Economics at Leicester University. He is also a member of the governing board of the Public Finance Foundation. His research interests include topics in public expenditure analysis and public sector management. His publications include (with C. V. Brown) Public Sector Economics and Political Economy of Bureaucracy. He is a consultant 
to various organisations on public sector issues and an editor of Public Money and Management.

David M. King was educated at the Universities of Oxford and York and is now a Senior Lecturer in Economics at the University of Stirling. His chief interest is local government finance. He has been economic adviser on local tax reform to the UK government, and he has also been consulted by other European countries. He has recently worked with the OECD on state and local finance in Eastern Europe. His publications in this field include two-books - Taxes on Immovable Property and Fiscal Tiers: The Economics of Multi-Level Government.

Peter J. Lambert is a Senior Lecturer in Economics at the University of York and a Research Associate at the Institute of Fiscal Studies in London. His research focuses on the measurement and redistribution of income through the tax and benefit system. $\mathrm{He}$ is author of many journal articles and of two books, $A d-$ vanced Mathematics for Economists and the Distribution and Redistribution of Income: A Mathematical Analysis.

Rosella Levaggi is an economist with Salford University Business Services. A graduate of the University of Genoa, she followed this up with a D. Phil. in Economics from the University of York. She is a chartered accountant and auditor and was a Research Fellow at the University of York. Her research interests are in applied econometrics, particularly in the field of public finance and intergovernmental relations, and she has recently worked on the development of a general equilibrium model for Italy. She is the author of numerous articles and books, including Fiscal Federalism and Grants-in-Aid.

David J. Pyle is a Senior Lecturer in Economics at Leicester University. He was previously a Teaching Fellow at the University of York and an economic adviser to the Home Office. His research interests include the analysis of taxation; the application of economic analysis to the study of criminal law, and management science, especially mathematical programming. $\mathrm{He}$ has published widely in these areas and his books include The Economics of Crime and Law Enforcement and Tax Evasion and the Black Economy. 
Ian Walker is Professor of Economics at Keele University and is a Research Fellow at the Institute for Fiscal Studies, London. His research interests include several issues in public and social policy such as the incentives and distributed effects of taxation and social security. His publications include papers in the $R \boldsymbol{e}$ view of Economic Studies and the Economic Journal. 